\title{
Flow cytometry as a tool to investigate nuclear senescence in symbiotic and pathogenic systems
}

\author{
G Lingua 1, GC Varese 1, A Trotta 2, A Fusconi 2, E Gnavi 2, G Berta 1* \\ 1 Universitá degli Studi di Torino, Dipartimento di Scienze e Tecnologie Avanzate, corso Borsalino 54, l-15100 Alessandria; \\ 2 Dipartimento di Biologia Vegetale, viale Mattioli 25, 1-10125 Torino, Italy
}

(Received 30 July 1996; accepted 23 September 1996)

Summary - Arbuscular mycorrhizae have been reported to moderate negative effects (growth inhibition, necrosis, death) caused by soil-borne pathogenic fungi. In this paper, we assessed root viability with two DNA fluorescent flow cytometry stains that can be usefully combined to evaluate chromatin changes. Nuclei were extracted from arbuscular mycorrhizal (Glomus mosseae) and non-mycorrhizal tomato roots, infected or uninfected with Phytophthora nicotianae var parasitica and watered with a low phosphate nutrient solution. Nuclei extracted from non-mycorrhizal roots infected with the pathogenic fungus showed lower fluorescence values after staining, compared to arbuscular mycorrhizal roots, suggesting that the presence of the pathogen may result in DNA loss and condensation. Infection by either fungus (symbiotic and pathogen) reduced the ratio of $4 \mathrm{c}$ to $2 \mathrm{c}$ nuclei in the differentiated root.

arbuscular mycorrhiza / chromatin / root pathogen / flow cytometry / senescence

Résumé - La cytométrie de flux comme moyen pour étudier la sénescence nucléaire dans des systèmes symbiotiques et pathogènes. Les mycorhizes arbusculaires sont connues pour réduire les effets négatifs (croissance, nécrose, mort) causés par les pathogènes telluriques. Dans ce travail, nous avons évalué par cytométrie de flux, la viabilité des racines, en utilisant deux colorants d'ADN qui, en combinaison, permettent d'estimer les changements au niveau de la chromatine. Les noyaux ont été extraits des racines de tomate mycorhizées ou non avec Glomus mosseae ou infectées ou non avec Phytophthora nicotiana var parasitica et ayant reçu une solution nutritive pauvre en phosphore. Les noyaux extraits des racines non mycorhizées, infectées avec le champignon pathogène, ont donné des valeurs plus faibles de florescence par rapport à ceux obtenus avec des noyaux extraits des racines mycorhizées. Cela suggère que la présence de champignons pathogènes se traduit au niveau de l'ADN par une perte de condensation. L'infection par les deux champignons (symbiotique et pathogène) réduit le rapport du nombre de noyaux $4 c$ par rapport aux $2 c$ dans les racines différenciées.

mycorhize arbusculaire / chromatine / cytométrie de flux / sénescence

* Correspondence and reprints 


\section{INTRODUCTION}

Soil-borne root pathogenic fungi generally produce extensive root necrosis. However, this may be moderated by the arbuscular mycorrhizal (AM) symbiosis (Lindermann, 1992; Hooker et al, 1994; Liu, 1995). In tomato plants, for example, arbuscular mycorrhizae significantly reduce root necrosis, decrease root infection by pathogens and reduce inhibition of plant growth (Caron et al, 1985, 1986; Cordier et al, 1996; Trotta et al, 1996). However, mechanisms of biocontrol are not well understood.

The analysis of events occurring at the cellular and nuclear level offer the opportunity to improve understanding of the mechanisms underlying biocontrol. The nuclei of senescing root cortical cells may be either strongly condensed or chromatolytic due to DNA loss. Evaluation of chromatin structure and DNA content is therefore a useful indicator of root viability. One method available to analyse these parameters is flow cytometry of nuclei extracted from tissues or organs, coupled to staining with 4',6-diamidino-2-phenylindole (DAPI) or propidium iodide (PI) DNA-specific dyes. This is a powerful technique and the use of these stains in combination has previously given information about both quantitative and structural chromatin variations in a variety of systems (Cowden and Curtis, 1981; Mazzini et al, 1983; Darzynkiewicz et al, 1984; Evenson et al, 1986; Sgorbati et al, 1986, 1993; Bonaly et al, 1987; Berta et al, 1990, 1996).

This paper describes the use of these techniques in the investigation of nuclear senescence in roots of non-AM and AM tomato plants, infected or uninfected with the pathogenic fungus Phytophthora nicotianae var parasitica.

\section{MATERIALS AND METHODS}

Tomato plants (Lycopersicon esculentum Mill cv Early Mech) were grown in quartz sand under controlled conditions (16/8 h light/dark photoperiod, $24 / 20{ }^{\circ} \mathrm{C}$ light/dark thermoperiod, $130 \mu \mathrm{mol} \mathrm{m} \mathrm{m}^{-2} \mathrm{~s}^{-1}$ light irradiance at pot height, fluorescent lamps Sylvania F36W/133ST, cool white) and fed on alternate days with a Long Ashton nutrient solution containing $32 \mu \mathrm{M}$ phosphate. Mycorrhizal plants were inoculated at sowing with the AM fungus Glomus mosseae (Nicol and Gerd) Gerdemann and Trappe (BEG12) by mixing colonized roots of leek (Allium porrum $\mathrm{L}$ ) into the growth substrate. After 1 month, some plants were infected with Phytophthora nicotianae var parasitica Breda De
Haar (isolate 201, subsequently referred to as $P$ parasitica). These four groups of plants were identified as: $\mathrm{C}=$ uninoculated and uninfected controls; $\mathrm{C}+\mathrm{P}=P$ parasitica-infected plants; $\mathrm{M}=\mathrm{AM}$ plants; $\mathrm{M}+\mathrm{P}=P$ parasitica-infected AM plants. Plants were harvested when they were 2 months old ( 1 month after $P$ parasitica infection) and the intensity of mycorrhizal infection (M\%) was calculated according to Trouvelot et al (1986). Only plants with $\mathrm{M} \%$ values higher than $40 \%$ were used for investigations.

For flow cytometry, fresh roots deprived of their apices were chopped with a razor blade in a petri dish, in the presence of a few drops of extraction buffer $(0.1 \%$ citrate, $0.5 \mathrm{M}$ Tween 20$)$. Nuclei were isolated after $30 \mathrm{~min}$ incubation in this medium by filtering through a $20 \mu \mathrm{m}$ nylon mesh.

\section{Propidium iodide staining}

Nuclei were diluted in $0.1 \%$ citrate, $0.1 \%$ triton $\mathrm{X}-100$ to obtain a concentration of $10^{5}$ nuclei $\mathrm{mL}^{-1}$, and then stained with $50 \mu \mathrm{g} / \mathrm{mL}$ PI. Polyscience beads $(4.2 \mu \mathrm{m})$ were used as a standard. This procedure provides qualitative information because of the way that $\mathrm{PI}$ binds to DNA; as $\mathrm{PI}$ is intercalating, highly decondensed chromatin is easier to stain (Biradar and Rayburn, 1994).

\section{4',6-diamidino-2-phenylindole staining}

The four samples were diluted with $0.4 \mathrm{M}$ dibasic phosphate to adjust the concentration of nuclei to $10^{5} \mathrm{~mL}^{-1}$. They were then stained with $5.6 \mu \mathrm{M}$ DAPI. Human lymphocytes (HL), previously fixed in $70 \%$ ethanol and stained with DAPI, were used as the internal standard. Nuclear fluorescence intensity was evaluated as a percentage of the intensity of $\mathrm{HL}$ fluorescence.

\section{Flow cytometry}

A Partec PAS IIIi instrument was used. For measurement of DAPI staining, a mercury arc lamp was used in conjunction with BG1, UG1 filters and a TK420 dichroic mirror to select the exciting wavelength (UV). DAPI fluorescence was detected using a GG415 barrier filter. For PI staining, an argon laser (wavelength = $488 \mathrm{~nm}$ ) was used as the exciting light source and a GG610 barrier filter was used to detect the fluorescence emission. Mean, integral (number of particles) and variation coefficients (CV\%) were calculated using 'Parteclist' (Partec GmbH, Münster, Germany). The ratio between the number of nuclei with 4c DNA and those with 2c DNA content was calculated and the data compared by analysis of variance (ANOVA). 


\section{Light microscopy}

Roots inoculated or not with $G$ mosseae were fixed for $2 \mathrm{~h}$ in $4 \%$ formaldehyde in $0.1 \mathrm{M}$ phosphate buffer, $\mathrm{pH}$ 7 , postfixed in $\mathrm{OsO}_{4} 1 \%$, dehydrated and embedded in Durcupan ACM (Fluka, Buchs, Switzerland). Median longitudinal sections were cut on a Reichert ultramicrotome, and nucleus morphology was examined using light microscopy (Zeiss Axiolab, Carl Zeiss Jena $\mathrm{GmbH}$, Jena, Germany), after staining with $1 \%$ toluidine blue in $1 \%$ sodium tetraborate.

\section{RESULTS}

\section{Propidium iodide staining}

Two peaks, belonging to two nucleus populations with $2 \mathrm{c}$ and $4 \mathrm{c}$ DNA content, were recognized after $P$ I staining. Nuclei from $M+P$ roots showed the highest fluorescence values, while those extracted from $C+P$ roots showed the lowest ones (table I and fig 1). CVs ranged from 6.38 to $11.06 \%$.
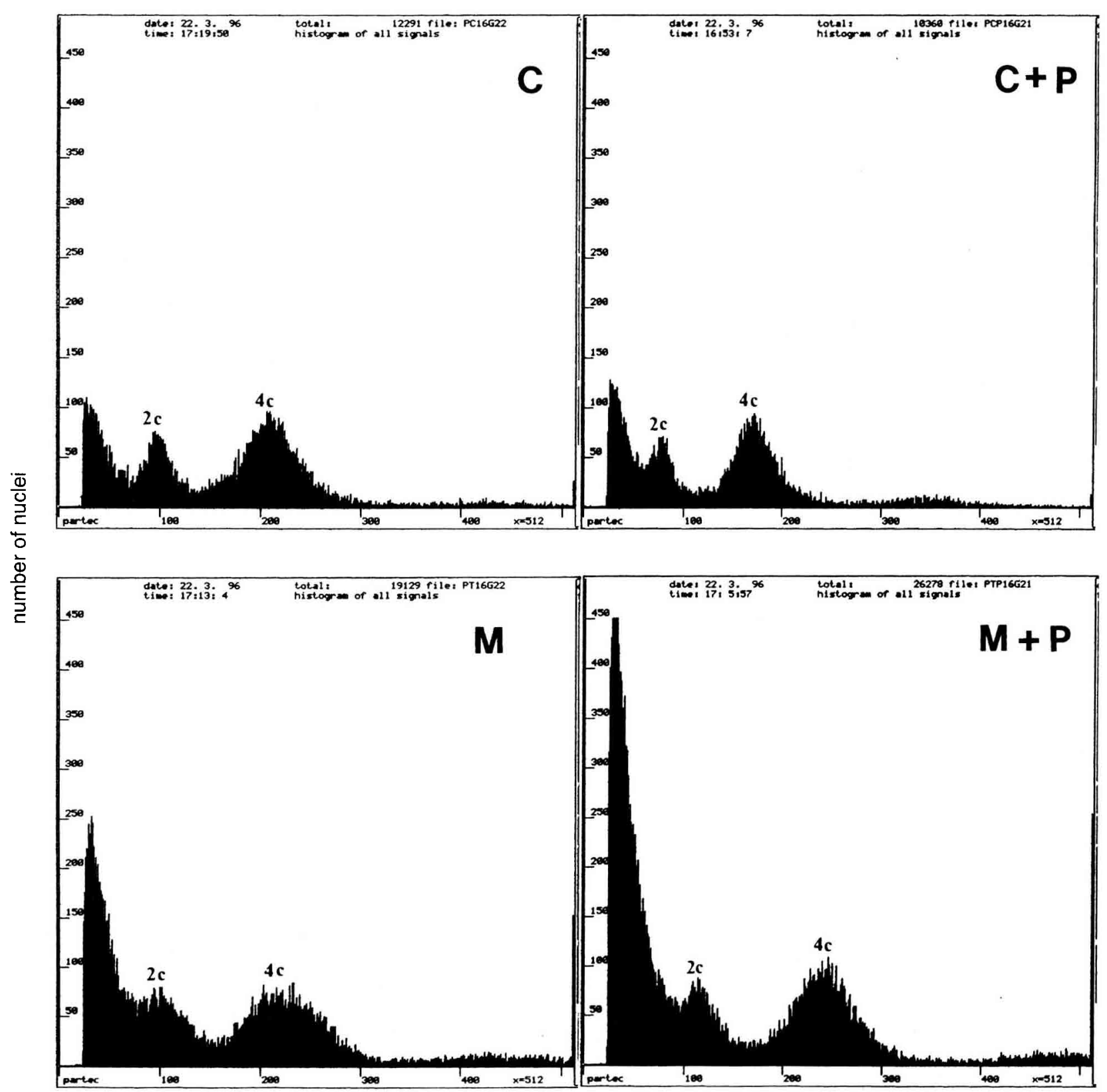

fluorescence intensity (au)

Fig 1. Flow cytometry histograms of propidium iodide $(\mathrm{PI})$-stained nuclei extracted from tomato roots. $\mathrm{C}$ : control plants; $\mathrm{C}+\mathrm{P}$ : Phytophthora nicotianae var parasitica-infected plants; $\mathrm{M}$ : arbuscular mycorrhizal plants; $\mathrm{M}+\mathrm{P}$ : Phytophthora nicotianae var parasitica-infected arbuscular mycorrhizal plants. In each histogram, the left peak represents the $2 \mathrm{c}$ nuclei population, the right one the $4 \mathrm{c}$ nuclei population. 


\section{4',6-diamidino-2-phenylindole staining}

Nuclei of M plants exhibited the highest fluorescence after DAPI staining, followed by those from the $\mathrm{M}+\mathrm{P}$ treatment (table II and fig 2). Those from $C$ and $C+P$ plants were very similar, but the $4 \mathrm{c}$ peak of $C$ roots had a higher fluorescence, while $2 \mathrm{C}$ nuclei from $\mathrm{C}+\mathrm{P}$ roots showed higher fluorescence. CVs ranged from 1.29 to $3.86 \%$, with the $\mathrm{C}+\mathrm{P}$ treatment having the highest values (table II).

In $\mathrm{C}$ plants, the mean ratio of $4 \mathrm{C}$ to $2 \mathrm{c}$ was higher than 3 , but below 4 (table III), and significantly different from values of both $\mathrm{C}+\mathrm{P}$ and $\mathrm{M}+\mathrm{P}(P<0.01)$ and $\mathrm{M}(P<0.05)$. These data were confirmed by PI staining (data not shown).

\section{Nuclear morphology - light microscopy analysis}

Nuclei in the differentiated part of uninfected roots were in a peripheral position in cells and were mostly lens-shaped (fig 3a). In $\mathrm{M}$ and $\mathrm{M}+\mathrm{P}$ roots, nuclei were often round or lobe-shaped and in a central position where the AM infection was well developed and especially in arbusculecontaining cells. Decondensed chromatin was clearly visible (fig $3 b$ ).

In contrast, nuclei were in a peripheral position, lens-shaped and pyknotic or weakly stained in $\mathrm{C}+\mathrm{P}$ roots (fig $3 \mathrm{C}$ ).

\section{DISCUSSION}

In various AM systems, the presence of the symbiotic fungus has been reported to result in significant hypertrophy of the host cell nucleus (Protsenko and Shemankova, 1971; Holley and Peterson, 1979; Toth and Miller, 1984; Sgorbati et al, 1993). Moreover, data obtained with a variety of techniques (Berta et al, 1986, 1990; Blair et al, 1988; Berta and Squadrone, 1993; Sgorbati et al, 1993) have shown that this nuclear hypertrophy is not due to polyploidization, but to an increase in chromatin decondensation.

Table I. Intensity of fluorescence of propidium iodide (PI)-stained nuclei for each of the four treatments.

\begin{tabular}{lcccc}
\hline & $\begin{array}{c}\text { Mean fluorescence } \\
\text { intensity of nuclei } \\
\text { with } 2 c \text { DNA content }\end{array}$ & $\begin{array}{c}\text { Variation coefficients } \\
(2 c \text { nuclei }) \\
(\%)\end{array}$ & $\begin{array}{c}\text { Mean fluorescence } \\
\text { intensity of nuclei } \\
\text { with } 4 c \text { DNA content }\end{array}$ & $\begin{array}{c}\text { Variation coefficients } \\
(4 c \text { nuclei }) \\
(\%)\end{array}$ \\
$\mathrm{C}$ & 86.5 & 6.38 & 181 & 6.56 \\
$\mathrm{C}+\mathrm{P}$ & 78 & 11.06 & 171.5 & 6.44 \\
$\mathrm{M}$ & 100 & 10.95 & 222.5 & 10.65 \\
$\mathrm{M}+\mathrm{P}$ & 115 & 8.36 & 242 & 8.67 \\
\hline
\end{tabular}

$\mathrm{C}$ : control plants; $\mathrm{C}+\mathrm{P}$ : Phytophthora nicotianae var parasitica-infected plants; $\mathrm{M}$ : arbuscular mycorrhizal plants; $\mathrm{M}+\mathrm{P}$ Phytophthora nicotianae var parasitica-infected arbuscular mycorrhizal plants.

Table II. Intensity of fluorescence of 4',6-diamidino-2-phenylindole (DAPI)-stained nuclei for each of the four treatments.

Mean fluorescence
intensity of nuclei
with 2c DNA content

Mean fluorescence with 2 c DNA content
Variation coefficients (2c nuclei)

(\%)

Mean fluorescence
intensity of nuclei
with 4 C DNA content

Mean fluorescence with $4 c$ DNA content
Variation coefficients (4c nuclei)

(\%)

$\begin{array}{llllr}C & 34.0 & 1.29 & 67.9 & 3.46 \\ C+P & 34.6 & 3.18 & 67.2 & 3.86 \\ M & 36.6 & 2.45 & 73.4 & 1.72 \\ M+P & 35.9 & 2.84 & 72.4 & 2.54\end{array}$


Chromatin decondensation is known to be related to transcription in both animal and plant cells (Nagl, 1985), and the shape and position of a nucleus is also thought to depend on its functional activity. In the $A$ porrum $+G$ mosseae system, round, centrally positioned nuclei, which are more common in the arbuscule-containing cortical cells, show higher labelling after ${ }^{3} \mathrm{H}$-uridine uptake than peripheral ones, indicating that they are more active (Berta et al, 1996).

The differences observed in the $4 \mathrm{c}$ to $2 \mathrm{c}$ ratio for tomato roots $+G$ mosseae in this study also point to the absence of polyploidization, and suggest that the presence of either a mycorrhizal and/or a pathogenic fungus in root tissues affects the host cell cycle, as in has been observed for mycorrhiza in $A$ porrum $+G$ mosseae (Berta et al, 1991).

Fluorescence of PI stained nuclei was lower in $C$ and $C+P$ than in $M$ and $M+P$ roots. The lower fluorescence values of the $C$ nuclei can be partly explained by chromatin condensation, indicating a lower transcriptional activity and sug-
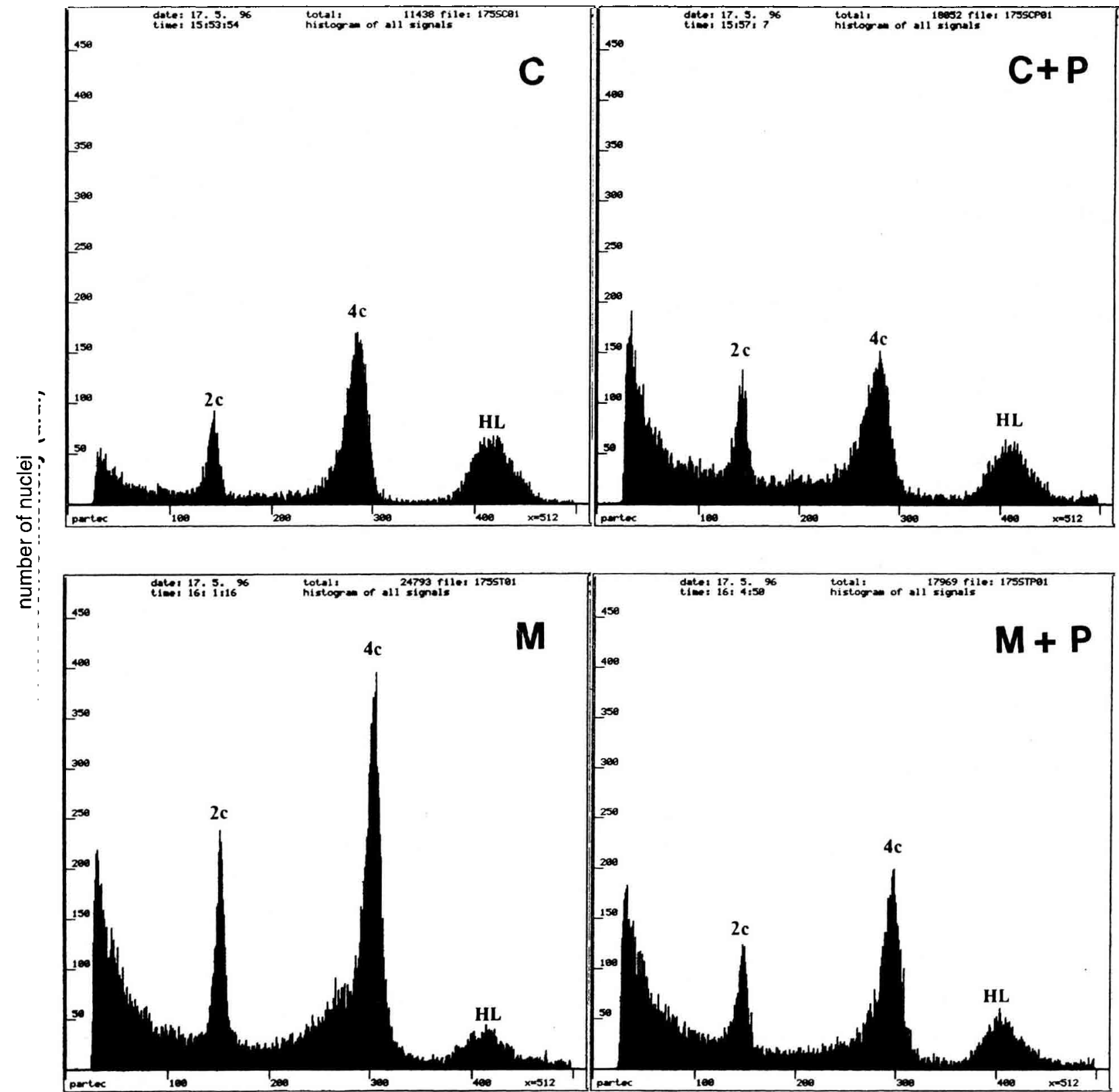

fluorescence intensity (au)

Fig 2. Flow cytometry histograms of 4',6-diamidino-2-phenylindole (DAPI)-stained nuclei extracted from tomato roots. C: control plants; C + P: Phytophthora nicotianae var parasitica-infected plants; M: arbuscular mycorrhizal plants; M + P: Phytophthora nicotianae var parasitica-infected arbuscular mycorrhizal plants. In each histogram, the left peak represents the $2 \mathrm{c}$ nuclei population, the central one the $4 \mathrm{c}$ nuclei population, and the right peak is given by the human lymphocytes $(H L)$ (standard). 
Table III. Ratio between the number of nuclei with $4 \mathrm{c}$ DNA content and number of nuclei with $2 c$ DNA content in five repetitions.

\begin{tabular}{|c|c|c|c|c|c|c|}
\hline & 1 & II & III & $I V$ & $V$ & Mean \\
\hline C & 3.90 & 3.05 & 4.29 & 3.98 & 3.83 & $3.81 \pm 0.21$ \\
\hline$C+P$ & 2.95 & 3.24 & 2.99 & 2.50 & 2.42 & $2.82 \pm 0.16$ \\
\hline M & 2.65 & 2.59 & 2.68 & 4.07 & 2.65 & $2.93 \pm 0.29$ \\
\hline$M+P$ & 2.89 & 2.87 & 2.09 & 2.36 & 2.34 & $2.51 \pm 0.16$ \\
\hline
\end{tabular}

Abbreviations as in table I.

gesting that the control roots are mostly ageing or senescing.

Nuclei of AM tomato plants were always most fluorescent after DAPI staining, as previously reported for other AM systems (Berta et al, 1986; Sgorbati et al, 1993). This may be attributable to replication of part of the DNA in nuclei from AM roots. The lower fluorescence of $C+P$ nuclei might be due to their partial fragmentation, as observed by light microscopy, or to direct DNA loss, through the stress imposed by the pathogenic fungus.
Both chromatin condensation (revealed by $\mathrm{PI}$ ) and DNA loss (evaluated by DAPI), which are clear signals of senescence whatever the reason (root age or pathogen infection), were reduced with AM colonization of tomato roots.

Useful information was also provided by comparisons of CVs of data obtained with the two stains. Data from PI staining generally exhibited high CVs: these data were less precise than those obtained with DAPI. It is of interest that the $\mathrm{CV}$ of $\mathrm{C}+\mathrm{P}$ were usually the highest, with both stains, suggesting that the $C+P$ population of

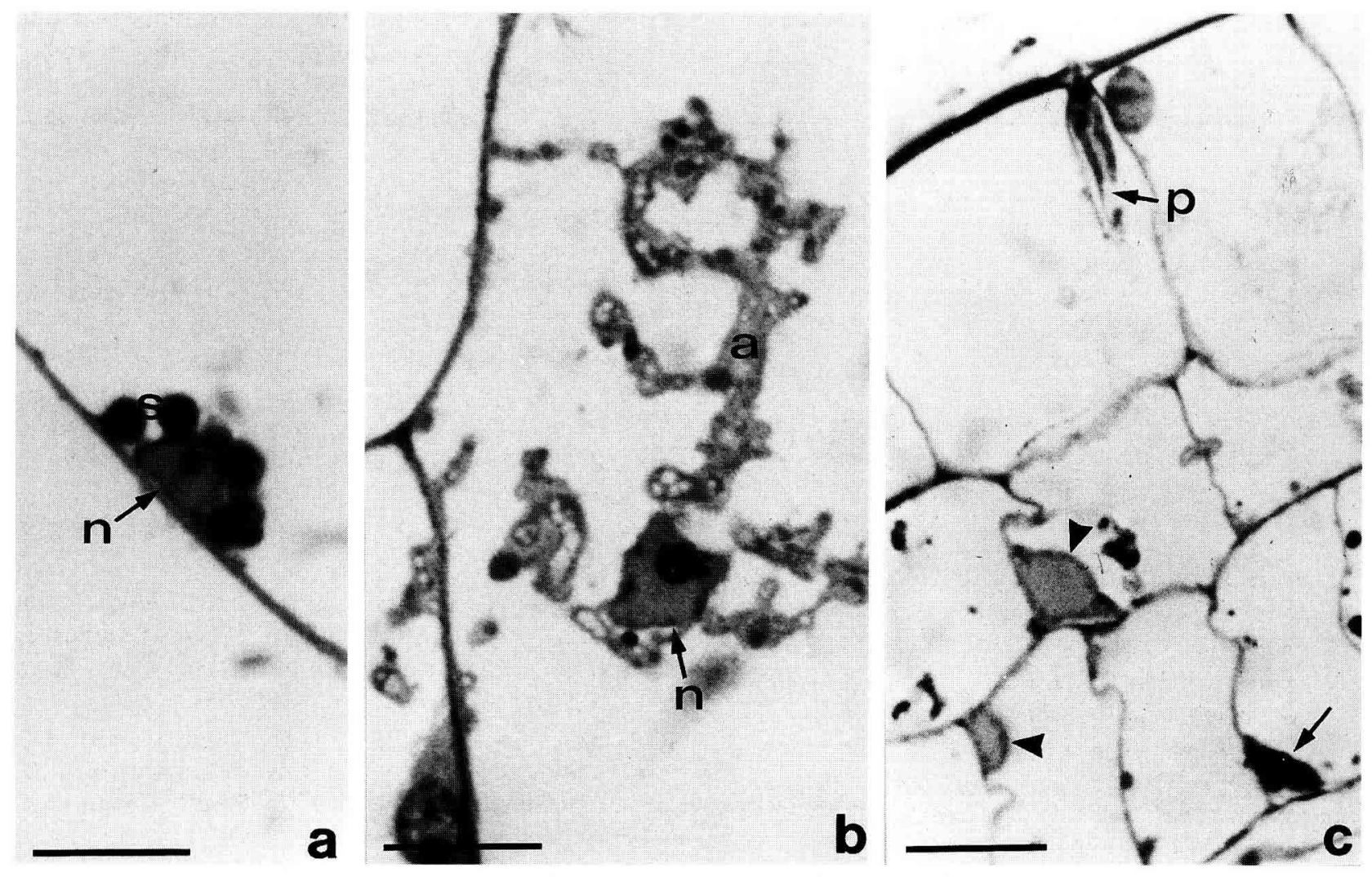

Fig 3. Nuclei in tomato root cortex tissue. a) Uninfected root, the nucleus ( $n$ ) with an evident nucleolus is adjacent to the cell wall, surrounded by starch grain (s); b) arbuscular mycorrhizal root, the nucleus $(n)$, in central position, shows decondensed chromatin, peripheral chromocentres and a large, round, nucleolus, a: arbuscule; c) Phytophthora nicotianae var parasitica-infected root, the nuclei are in lateral position, pyknotic (arrow) or weakly stained (arrowheads); p: pathogenic hypha. Horizontal bars represents $10 \mu \mathrm{m}$. 
nuclei was the least homogeneous of the four analyzed.

In conclusion, our results show that flow cytometry gives valuable information about root senescence and suggests that it could be especially useful in investigating the effects of $A M$ and pathogenic fungi on plant cell nuclei.

\section{ACKNOWLEDGMENTS}

This work has been supported by EU grant, AIR project $n^{\circ}$ 3-CT 94-0809 and, partly, by Italian MURST. The authors wish to thank Dr L Mele (Servizio di Immunoematologia e Trasfusione, Azienda Ospedaliera SS Antonio e Biagio, Alessandria, Italy) who kindly provided the human lymphocytes.

\section{REFERENCES}

Berta G, Squadrone S (1993) Nuclear structure in root cortical cells of a vesicular arbuscular mycorrhiza, as affected by differentiation and the presence of the fungus. G Bot it 127, 303-305

Berta G, Sgorbati S, Soler V, Fusconi A, Trotta A, Citterio A, Bottone MG, Sparvoli E, Scannerini S (1990) Variations in chromatin structure in host nuclei of a vesicular arbuscular mycorrhiza. New Phytol 114, 199-205

Berta G, Tagliasacchi AM, Fusconi A, Gerlero D, Trotta A, Scannerini $S$ (1991) The mitotic cycle in root apical meristems of Allium porrum $L$ is controlled by the endomycorrhizal fungus Glomus sp strain E3. Protoplasma 161, 12-16

Berta G, Fusconi A, Lingua G, Trotta A, Sgorbati S (1996) Influence of arbuscular mycorrhizal infection on nuclear structure and activity during root morphogenesis. In: Mycorrhizas in Integrated Systems from Genes to Plant Development. Proceedings of the Fourth European Symposium on Mycorrhizas (C Azcón-Aguilar, JM Barea, eds), Office for Official Publications of the European Communities, Luxembourg, 174-177

Biradar DP, Rayburn AL (1994) Flow cytometric probing of chromatin condensation in maize diploid nuclei. New Phytol 126, 31-35

Blair DA, Peterson RL, Bowley SR (1988) Nuclear DNA content in root cells of Lotus and Trifolium colonized by the VAM fungus, Glomus versiforme. New Phytol 109, 167-170

Bonaly J, Bre MH, Lefort-Tran M, Mestre JC (1987) A flow cytometric study of DNA staining in situ in exponentially growing and stationary Euglena gracilis. Cytometry 8, 42-45

Caron M, Fortin JA, Richard C (1985) Influence of substrate on the interaction of Glomus intraradices and Fusarium oxysporum $\mathrm{f} \mathrm{sp}$ radicis-lycopersici on tomatoes. Plant Soil 87, 233-239
Caron M, Fortin JA, Richard C (1986) Effect of phosphorus concentration and Glomus intraradices on Fusarium crown and root rot of tomatoes. Phytopathology 76, 942-945

Cordier C, Gianinazzi-Pearson V, Gianinazzi S (1996) Studies of spatial-temporal colonisation of root tissues by Phytophthora nicotianae var parasitica related to reduced disease in mycorrhizal tomato. Plant Soil (in press)

Cowden RR, Curtis SK (1981) Microfluorimetric investigations of chromatin structure 1. Evaluation of nine DNA-specific fluorochromes as probes of chromatin organization. Histochemistry 72, 11-23

Darzynkiewicz Z, Traganos F, Kapuscinski J, StaianoCoico L, Melamed MR (1984) Accessibility of DNA in situ to various fluorochromes: relationship to chromatin changes during erythroid differentiation of Friend leukemia cells. Cytometry 5, 355-363

Evenson D, Darzynkiewcz Z, Jost L, Janca F, Ballechey $B$ (1986) Changes in accessibility of DNA to various fluorochromes during spermatogenesis. Cytometry 7, 45-53

Holley D, Peterson RL (1979) Development of a vesicular-arbuscular mycorrhiza in bean roots. Can J Bot $57,1960-1978$

Hooker JE, Jaizme-Vega M, Atkinson D (1994) Biocontrol of plant pathogens using arbuscular mycorrhizal fungi. In: Impact of Arbuscular Mycorrhizas on Sustainable Agriculture and Natural Ecosystems (S Gianinazzi, H Schüepp, eds), Birkhäuser-Verlag Basel, Switzerland, 191-200

Lindermann RG (1992) Vesicular-arbuscular mycorrhizae and soil microbial interactions. In: Mycorrhizae in Sustainable Agriculture. ASA Special Publication no 54, 45-70

Liu RJ (1995) Effect of vesicular-arbuscular mycorrhizal fungi on Verticillium wilt cotton. Mycorrhiza 5 , 293-297

Mazzini G, Giordano P, Riccardi A, Montecucco CM (1983) A flow cytometric study of the propidium iodide staining kinetics of human leukocytes and its relationship with chromatin structure. Cytometry 3 , 443-448

Nagl W (1985) Chromatin organization and control of gene activity. Int Rev Cytol 94, 21-56

Protsenko MA, Shemankova NM (1971) An influence of a mycorrhizal-forming fungus on the sizes of nucleus and nucleolus in root cells of Pisum sativum. Mykol Fitopatol 5, 335-338

Sgorbati S, Levi M, Sparvoli E, Trezzi F, Lucchini G (1986) Cytometry and flow cytometry of 4',6diamidino-2-phenylindole (DAPI)-stained suspensions of nuclei released from fresh and fixed tissues of plants. Physiol Plant 68, 471-476

Sgorbati S, Berta G, Trotta A, Schellenbaum L, Citterio S, Dela Pierre M, Gianinazzi-Pearson V, Scannerin $S$ (1993) Chromatin structure variation in successful and unsuccessful arbuscular mycorrhizas of pea Protoplasma 175, 1-8 
Toth R, Miller RM (1984) Dynamics of arbuscule development and degeneration in Zea mays mycorrhiza. Am J Bot 7, 449-460

Trotta A, Varese GC, Gnavi E, Fusconi A, Sampó S, Berta G (1996) Interactions between the soilborne root pathogen Phytophtora parasitica and the arbuscular mycorrhizal fungus Glomus mosseae in tomato plants. Plant Soil (in press)
Trouvelot A, Kough JL, Gianinazzi-Pearson V (1986) Mesure du taux de mycorhization VA d'un système radiculaire. Recherche de méthodes d'estimation ayant une signification fonctionnelle. In: Physiological and Genetical Aspects of Mycorrhizae (V Gianinazzi-Pearson, S Gianinazzi, eds), 1st ESM, Dijon, 1-5 July 1985, INRA, Paris, France, 217-221 